それぞれの時代に結晶化された社会の思考が現れている。共同的社会生活から析出 される集合的所産としての「概念」が，「それ自身の進化の階梯」を経て「科学と いう普遍概念」に至り，社会を有機的に統合することができる．だが，こうした 「社会化された理性」への信頼，そのような形で温存されてきた「普遍的なもの」 への信仰を，私たちはそうそう簡単に共有することはできない. この時，モンテス キューがもう 1 つの参照枠として浮かび上がってくる.

モンテスキューは,「多様性」と「多元性」,「分裂」と「流動性」を「社会の基 本的な姿」とみている. かの有名な「三権分立」の理念も，「種類や質の違うもの が無限にちりばめられた世界」の「多様なる姿を守るための方法」として提起され ている. 分裂こそが各部分の相互作用を活発化させ，「他なるものへの想像力」を 呼び起こし，社会を繁栄に導く，権力を抑制する政治体制を好ましいものとするの は，多様性と相互性がある状態にこそ「社会が現われる」と考えるからである。し たがって，この世界に求められる「正義」は，特定の道徳的格率に還元されるもの ではなく，多様性と分裂を抱えたまま人間がともに「社会をなす」ことを可能にす る条件を指す。この意味での正義を実現するために要求される理性が「エスプリ」 である。それは「多元性のある社会を釣合いよく成り立たせる知の力」であり， 「法の精神」とは，すべての習俗や法律を超越し，「相対比較ができる位置に視点を 置いて, それらの間にある関係性について論じようという方法」を指す (234 頁). このように「モンテスキューは, 普遍概念すなわち完全さの理想を追うこと自体が, そのまま暴力となる可能性に, 明らかに気づいていた」と中江はいう (271 頁). 相容れない多様性がひしめき合う世界をともに生きていくための知＝エスプリの再 構成が, 今こそ求められていることはいうまでもない. 本書の触発を受けて, モン テスキューを読み直すことの意味は確かにある，と思える．思想史的考察を現代の 理論的課題へと結びつけ, 古典のテクストを再活性化させる, 鮮やかな読解の集積 である。

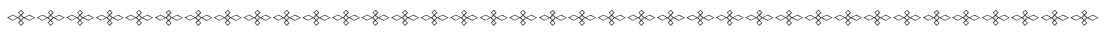

伊藤美登里 著

\title{
『ウルリッヒ・ベックの社会理論 リスク社会を生きるということ』
}

(勁草書房, 2017 年, 四六判, 248 頁, 2,800 円+税)

三上 剛史 (追手門学院大学教授)

本書の主な目的は, ウルリッヒ・ベックの社会学理論の主要部分を紹介すること にあると，冒頭で著者は述べている，本書の著者は，これまでベックの社会学を日 本に紹介することに大きく貢献してきた研究者であり, ベックの理論を語るに当た 
って最良の書き手であるといえるだろう。

ベックは「リスク社会」という用語とともに語られることが多いのであるが, 彼 の業績は多岐にわたっている。「第二の近代」「再帰的近代」「個人化」「グローバル 化」などについて多くの業績を残しているのであるが, 著者はベックの最大の功績 は，第一の近代から第二の近代への社会構造の変化を捉える理論的枠組みとして, 「再帰的近代化」理論を提唱したことにあるという解釈を示している.

全体は 7 つ章と終章とからなるが, 第 1 章で再帰的近代化論を論じ, 第 2 章で リスク社会, 第 3 章ではリスク概念の吟味, 第 4 章は個人化を扱っている. 第 5 章 と第 7 章は，著者がドイッで実施したフィールド調査にも基づいてベック理論の可 能性について論じたものである. また第 6 章は, 再帰的近代化論の主な構成要素で あるコスモポリタン化とコスモポリタニズムについて解説したものである.

第 1 章で著者は,「再帰的近代化論は, ベックの社会学理論の全体を総括するよ うな位置にある」として, ベックにおける再州的近代化論の重要性を指摘している. ベックの理論構成の中心を再帰的近代化論にみて全体を構成し直すのは著者の独自 性であり，理論書としても読むことのできる本書の意義を高めている.

よく知られているように, ベックは A. ギデンズ, S. ラッシュとともに『再帰的 近代化』という書物を刊行しているが，ギデンズらと共有する再帰的近代論がベッ クの社会理論全体を特徴づける主要な要素となっている点が丁寧に解説されている.

第 2 章はリスク社会についてである. ベックのリスク社会論についてはすでによ く知られているが，ここで著者が重視しているのは「このような状況をベックは連 帯を作り出すチャンスへと転換することを目論む」という点である.『危険社会』 の段階では, ベックはまだ「サブ政治」を一定範囲で育てるという見通しに留まっ ていたが，2000 年代に入ると，グローバルな規模で「政治的なもの」を作り出す 必要があると考えるようになる，そして政治は「中心のない状態」になったという. 「中心のない状態」のベック的認識と, それとは異なった意味での「中心のない社 会」を説くN.ルーマンとの対比などに思いをめぐらすならば，読者の興味は尽き ないであろう.

前章がリスク社会について語るものであったとすると, 第 3 章は, ベックにおけ る「リスク」および「危険」という言葉の用法について検討を付すものである.ル ーマンやC. ラウが行っている概念規定の明晰さに比べるとベックの概念規定は曖 昧であるが, ベックにとって重要だったのは, リスクの概念を厳密に規定すること ではなく，「リスク社会」の現実を描写し分析することであったのだと，著者はみ ている.

第 4 章は第二の近代におけるベックの個人化論を紹介するものである. ベックの 『危険社会』の邦訳旧版には, 個人化を扱った第 2 部が訳出されていなかったが, 著者は，この部分を新たに訳出した新版訳書の共訳者である，それだけに，ベック 理論における個人化論の位置とその重要性についてはうまくまとめられている.

個人化論におけるべックの独自性は, 再帰的近代における個人化は「何らかの集 
団に再び埋め込まれることのない解き放ちであり，この意味において，歴史上はじ めて個人が社会の再生産の単位となった」と主張する点にある. そこに, ベック独 特の用語である「準主体（Quasi-Subjet）」という言葉が登場するのであるが，「自 己語り」によって「そのつど構成される」主体である,「ネットワークの結節点と して存在する」準主体のありようが，E.H. エリクソンのアイデンティティ概念や， G. H. ミードの自我論などと比較され，的確に解説されている.

もう紙幅が尽きようとしている．残りの 3 つの章と終章を紹介することができな いのは残念であるが，この先は，読者自ら本書を手にとってお読みいただきたい．

冒頭部でも少し触れたが，著者がドイツに扔いて実施した調查は，ドイツ社会にお けるリスク社会の現実や，福祉政策の実情等が伝わってきて，大変興味深い，評者 もドイツで同様の調査に参加したことがあるが，ドイツ社会におけるキリスト教会 や赤十字社の存在感がよく描かれており臨場感もある.

特に注文したい点がある訳ではないが，あくまでもべック社会理論の紹介に徹す る姿勢が貫かれているがゆえに，そこからさらに踏み込んだ理論的検討が禁欲され ているのは止むを得ないと思う，今後，ベックを超える著者独自の社会理論が練り 上げられてゆくのが楽しみである。

松井広志 著

\section{『模型のメディア論——時空間を媒介する「モノ」』}

(青弓社, 2017 年, A5 判, 242 頁，3,000円+税)

近森 高明 (慶應義塾大学文学部教授)

本書は,「模型」というモノがメディアとして形成される歴史を問う「模型のメ ディア史」を展開すると同時に，近年の物質性をめぐる理論的動向を踏まえた「モ ノのメディア論」を構想するものである.

全体は 3 部で構成され，第 1 部「歴史」と第 2 部「現在」では, 各時代ごとに画 期となる模型のジャンルに着目しつつ，それぞれの製作の主体，材料や技術，諸制 度や産業との関連などを踏まえ，メデイアとしての特徵を抽出するという流れにな っている．また第 3 部「理論」では，ポピュラー文化に扔ける「モノ」の受容に接 近する理論枠組みを検討しながら，インターネット・モバイル時代の「モノのメデ イア論」を構想するという流れになっている．以下，「歴史」と「現在」の概要を みてみよう。

まず戦前期の模型は, 飛行機や鉄道などを科学的視点からとらえる「科学模型」 であった，木製や金属製で，製作主体としては「少年技師」が想定され，形状より 